\title{
Structural Conservation and Food Habit-related Liver Expression of Uncoupling Protein 2 Gene in Five Major Chinese Carps
}

\author{
Wan-Qin Liao ${ }^{1}$, Xu-Fang Liang ${ }^{1, *}$, Lin Wang', Ling Fang ${ }^{1}$, Xiaotao Lin ${ }^{1}$, Junjie Bai ${ }^{2}$ and Qing Jian ${ }^{2}$ \\ ${ }^{1}$ College of Life Science and Technology, Jinan University, Shipai, Guangzhou 510632, China \\ ${ }^{2}$ Pearl River Fisheries Research Institute, Ministry of Agriculture, Fangcun, Guangzhou 510380, China
}

Received 30 October 2005, Accepted 20 December 2005

The full-length cDNA of grass carp (Ctenopharyngodon idellus) and silver carp (Hypophthalmichthys molitrix) uncoupling protein 2 (UCP2) was obtained from liver. The grass carp UCP2 cDNA was determined to be 1152 bp in length with an open reading frame that encodes 310 amino acids. Five introns (Intron 3, 4, 5, 6 and 7) in the translated region, and partial sequence of Intron 2 in the untranslated region of grass carp UCP2 gene were also obtained. Gene structure comparison between grass carp and mammalian (human and mouse) UCP2 gene shows that, the UCP2 gene structure of grass carp is much similar to that of human and mouse. Partial UCP2 cDNA sequences of bighead carp (Aristichthys nobilis) and mud carp (Cirrhinus molitorella), were further determined. Together with the common carp (Cyprinus carpio) UCP2 sequence from GenBank (AJ243486), multiple alignment result shows that the nucleotide and amino acid sequences of the UCP2 gene, were highly conserved among the five major Chinese carps that belong to four subfamilies. Using beta-actin as control, the ratio UCP2/beta-actin mRNA (\%) was determined to be $149.4 \pm 15.6$ (common carp), $127.4 \pm 22.1$ (mud carp), 96.7 \pm 12.7 (silver carp), 94.1 \pm 26.8 (bighead carp) and $63.7 \pm 16.2$ (grass carp). The relative liver UCP2 expression of the five major Chinese carps, shows a close relationship with their food habit: benthos and detrituseating fish (common carp and mud carp) $>$ planktivorious fish (silver carp and bighead carp) $>$ herbivorious fish (grass carp). We suggest that liver UCP2 might be important for Chinese carps to detoxify cyanotoxins and bacteria in debris and plankton food.

Keywords: Chinese carps, Detoxification, Food habit, Gene structure and expression, Liver, Reactive oxygen species, Uncoupling protein 2

\footnotetext{
*To whom correspondence should be addressed.

Tel: 86-20-8522-1497; Fax: 86-20-8522-6262

E-mail: tliangxf@jnu.edu.cn
}

\section{Introduction}

Uncoupling protein (now UCP1) is a demonstrated uncoupler of oxidative phosphorylation (Nicholls and Locke, 1984). UCP1 expression is restricted to mammalian brown adipose tissue, where it provides a pathway for protons (pumped out of the mitochondrial matrix by the electron transport chain) to pass back in. The futile cycling of proton pumping and leaking, allows an augmentation of heat production in this tissue. As the high sequence similarity of the UCP2 to UCP1, early hypotheses for its physiological role has focused on thermogenesis. However, Stuart et al. (1999) have identified uncoupling protein 2 (UCP2) from a common carp (Cyprinus carpio) peritoneal exudates cell cDNA library, and from a zebrafish (Danio rerio) day 0 fin regeneration cDNA library. Heat is conducted, and thus dissipated, in water at a rate some 25 times that in air. In fish, such as carp, where specific anatomical adaptations to retain metabolic heat (e.g. epidermal fat layers) are absent, a strategy of active thermogenesis is untenable. The presence of UCP2 in fish (ectothermic vertebrate), strongly suggests that UCP2 may have function(s) not related to thermogenesis (Stuart et al., 1999).

Whereas little is known at present about the physiological regulation of fish UCP2 gene in vivo (Liang et al., 2003), the work on mammalian UCP2 gene expression has revealed a tissue distribution pattern related to lipid oxidation (Fleury et al., 1997; Samec et al., 1998; Ricquier and Bouillaud, 2000). A study by Echtay et al. (2002) indicates that the interaction of superoxide with UCPs may be a mechanism for decreasing the concentrations of reactive oxygen species (ROS) inside mitochondria.

Liver is the major site in fish and other vertebrates for the detoxification of ingested toxic materials (e.g. cyanobacterial toxins) by oxidation, and ROS is known to be involved in the process (Hermansky et al., 1991; Ding et al., 1998; Gehringer et al., 2003). Cyanotoxins produced by freshwater cyanobacteria are very common worldwide, especially in China. Many experimental studies have been conducted to document the 
toxicity of microcystin exposure through gastrointestinal way on benthos and detritus-eating fish such as common carp (Rabergh et al., 1991; Fischer and Dietrich, 2000; Li et al., 2001; Wu et al., 2002), and planktivorous fish such as silver carp (Hypophthalmichthys molitrix) (Xie et al., 2004). Our previous work on fish UCP2 gene expression in vivo, has found that UCP2 was expressed in the liver of red sea bream Pagrus major (Liang et al., 2003). The purpose of this study was to compare the gene structure and liver expression of UCP2 among five major Chinese carps with distinctive food habit, which would shed a new light on the physiological function of vertebrate UCP2 gene.

\section{Materials and Methods}

Fish sampling. Grass carp (Ctenopharyngodon idellus), silver carp, bighead carp (Aristichthys nobilis), mud carp (Cirrhinus molitorella) and common carp, used in this study, were caught in Xiangang Reservoir (Boluo). Randomly selected fish were killed, and livers were dissected immediately after capture for RNA isolation. Five fish for each species were sampled.

\section{Amplification of the partial cDNA sequence of the major Chinese carp UCP2 gene. Total RNA was isolated using SV Total RNA Isolation System (Promega). Reverse transcription was performed with oligo $(\mathrm{dT})_{18}$ primer using First Strand cDNA Synthesis Kit (Toyobo). Two degenerate primers were designed to clone partial UCP 2 cDNA sequences of the major Chinese carps by PCR: 5'-TTTCCACTGGACACCGCAAAA(G)GT-3' (designated as UCP01F), and 5'-GTGACAAACATAACCACA(G)TTCA-3' (designated as UCP02R). The PCR parameters were 30 cycles of $94^{\circ} \mathrm{C}$ for $1 \mathrm{~min}, 50^{\circ} \mathrm{C}$ for $1 \mathrm{~min}$ and $72^{\circ} \mathrm{C}$ for $1 \mathrm{~min}$, with an additional initial $3-\mathrm{min}$ denaturation at $94^{\circ} \mathrm{C}$ and a 5 -min final extension at $72^{\circ} \mathrm{C}$. PCR product of the expected length for UCP01F/UCP02R (775 bp) was purified from agarose gel, and cloned into the pGEM-T Easy vector (Promega). Insert was sequenced using an $\mathrm{ABI}$ Prism ${ }^{\mathrm{TM}} 377$ (Perkin Elmer).}

Full-length cDNA amplification of grass carp and silver carp UCP2 gene by 5' and 3'RACEs. Six common gene-specific primers were designed in the cloned PCR fragments of grass carp and silver carp UCP2 cDNA for 5'-RACE and 3'-RACE (Table 1). 5'-RACE was performed using a 5'-Full RACE Core Set (TaKaRa). RNA was reverse-transcribed to cDNA with $10 \mu \mathrm{M}$ phosphorylated primer UCP 5'RT. After digestion with RNase $\mathrm{H}$ at $30^{\circ} \mathrm{C}$ for $60 \mathrm{~min}$, the cDNA in $12 \mu \mathrm{l}$ of water was incubated for $18 \mathrm{~h}$ at $16^{\circ} \mathrm{C}$ with $1 \mu \mathrm{l}$ of T4 RNA ligase (40 units), $8 \mu$ of $5 \times$ RNA ligation buffer and $20 \mu \mathrm{l}$ of $40 \%$ poly (ethylene glycol) 6000 to ligate the 5 '-end to the 3 '-end. The circular cDNA was used as template. In the first PCR, the circular cDNA was amplified with $0.2 \mu \mathrm{M}$ each of primers UCP5'S1 and UCP5'A1. In the second PCR, primers UCP5'S2 and UCP5'A2 were used. The 5'-RACE-PCR product was purified from agarose gel, cloned into the pGEM-T Easy vector and sequenced.

3'-RACE was performed using a 3'-Full RACE Core Set (TaKaRa). RNA was reverse-transcribed to cDNA in the presence of oligo(dT)-3 site adaptor primer using a sequential program of
Table 1. Common PCR primer sequences for RACE of both grass carp (Ctenopharyngodon idellus) and silver carp (Hypophthalmichthys Molitrix)

\begin{tabular}{cc}
\hline Name of primer & \multicolumn{1}{c}{ Sequence of primer } \\
\hline 5'RACE & \\
UCP5'RT & 5'-(P)TCAACCTACTGCCA-3' \\
UCP5'S1 & 5'-ACTGCAGCGTCAGATGAG-3' \\
UCP5'A1 & 5'-ACCGGACCATGGCCTGTGTT-3' \\
UCP5'S2 & 5'-TCTGTACGCATTGGCCTCTA-3' \\
UCP5'A2 & 5'-TTGCGGTGTCCAGTGGAA-3' \\
3'RACE & \\
UCP3'S & 5'-TCCTCGCTGATGACTGATGA-3' \\
\hline
\end{tabular}

$30^{\circ} \mathrm{C}$ for $1 \mathrm{~min}, 50^{\circ} \mathrm{C}$ for $30 \mathrm{~min}$ and $95^{\circ} \mathrm{C}$ for $5 \mathrm{~min}$. The prepared cDNA was amplified by PCR with $0.2 \mu \mathrm{M}$ primer UCP3'S (Table 1) and $0.2 \mu \mathrm{M} 3$ site adaptor primer of 3'-Full RACE Core Set. The 3'-RACE-PCR product was purified from agarose gel, cloned into the pGEM-T Easy vector and sequenced.

The full-length UCP2 cDNAs of grass carp and silver carp were confirmed by PCR with primers designed from the 5'-end and 3'end sequences of the cloned UCP2 cDNAs. These primers were UCP03F: 5'-TTCAACACATTCCGCTTC-3' and UCP04R: 5'CCAAAGATCAAGTTTAATAGACATG-3' for grass carp UCP2 gene, and UCP05F: 5'-TGGAGCAGAGCACCTGCGTT-3' and UCP06R: 5'-GGCAGATTCTGAAAGACAG-3' for silver carp $\mathrm{UCP} 2$ gene. The PCR parameters were 30 cycles of $94^{\circ} \mathrm{C}$ for $1 \mathrm{~min}$, $57^{\circ} \mathrm{C}$ for $1 \mathrm{~min}$, and $72^{\circ} \mathrm{C}$ for $90 \mathrm{~s}$.

Amplification of intronic DNA of grass carp UCP2 gene. Genomic DNA was isolated using Blood \& Cell Culture DNA Kit (QIAGEN) according to the manufacture's recommendations. Universal Genome Walker Kit (Clontech) was used for cloning the partial sequence of Intron 2 of grass carp UCP2 gene. Grass carp genomic DNA $(2.5 \mu \mathrm{g})$ was digested at $37^{\circ} \mathrm{C}$ overnight with DraI, and the digested blunt end DNAs were purified by phenol extraction and ethanol precipitation. DNA was then ligated to the Genome Walker adaptor at $16^{\circ} \mathrm{C}$ overnight. To stop the reactions, each sample was incubated at $70^{\circ} \mathrm{C}$ for $5 \mathrm{~min}$ and $72 \mu \mathrm{TE}(10 / 1$, $\mathrm{pH}$ 7.5) was added. After the library was constructed, two touchdown PCR amplifications of the library were conducted. Primary PCR was performed using the following two-step cycle procedure. The genomic library was amplified for 7 cycles at $94^{\circ} \mathrm{C}$ for $25 \mathrm{~s}$ and $72^{\circ} \mathrm{C}$ for $3 \mathrm{~min}$, and 32 cycles at $94^{\circ} \mathrm{C}$ for $25 \mathrm{~s}$ and $67^{\circ} \mathrm{C}$ for $3 \mathrm{~min}$ in the presence of an outer adaptor primer (AP1, 5'GTAATACGACTCACTATAGGGC-3') and the outer gene-specific primer (GSP1，5'-GTAGGAGGCACATCACCAGCTCTGAA-3'), followed by additional treatment at $67^{\circ} \mathrm{C}$ for $7 \mathrm{~min}$. The primary PCR mixture was then diluted 50 times with deionized water, and used as a template for a secondary PCR with the nested adaptor primer (AP2, 5'-ACTATAGGGCACGCGTGGT-3') and the nested gene-specific primer (GSP2, 5'-GAAGTCGGAATCACAGGAAT GTAACA-3'). The secondary PCR was performed for five cycles at $94^{\circ} \mathrm{C}$ for $25 \mathrm{~s}$ and $72^{\circ} \mathrm{C}$ for $3 \mathrm{~min}$, and for 20 cycles at $94^{\circ} \mathrm{C}$ for $25 \mathrm{~s}$ and $67^{\circ} \mathrm{C}$ for $3 \mathrm{~min}$. The final PCR product was analyzed on agarose gel electrophoresis, cloned into pGEM-T Easy vector and sequenced. 
Table 2. Primer sequences for intron amplification

\begin{tabular}{cl}
\hline Name of primer & \multicolumn{1}{c}{ Sequence of primer } \\
\hline UCPI1 & 5'-TTCCACTGGACACCGCAA-3' \\
UCPI2 & 5'-ACCGGACCATGGCCTGTGTT-3' \\
UCPI3 & 5'-TCTGTACGCATTGGCCTCTA-3' \\
UCPI4 & 5'-ATAGGTCACCAGCTCAGTGCAG-3' \\
UCPI5 & 5'-CTGCACTGAGCTGGTGACCTAT-3' \\
UCPI6 & 5'-GCAGATGTGAAGTGGCAGG-3' \\
UCPI7 & 5'-CCTGCCACTTCACATCTG-3' \\
UCPI8 & 5'-GCTGTTCGTAGGTGACAA-3' \\
\hline
\end{tabular}

Primers for PCR amplification of Introns 3, 4, 5, 6 and 7 of grass carp UCP2 gene are listed in Table 2. UCPI1 and UCPI2 for Intron 3, UCPI3 and UCPI4 for Intron 4 and Intron 5, UCPI5 and UCPI6 for Intron 6, and UCPI7 and UCPI8 for Intron 7. PCR was performed in $50 \mu \mathrm{l}$ reaction containing 200-300 ng genomic DNA. The following cycle was used for amplification: denaturation for $1 \mathrm{~min}$ at $94^{\circ} \mathrm{C}$, annealing for $1 \mathrm{~min}$ at $55^{\circ} \mathrm{C}$, and extension for $1 \mathrm{~min}$ at $72^{\circ} \mathrm{C}$. These steps were repeated for 30 cycles with an additional initial 3-min denaturation at $94^{\circ} \mathrm{C}$ and a 5-min final extension at $72^{\circ} \mathrm{C}$. The genomic PCR products were sequenced after cloned into pGEM-T Easy vector.
Quantitation of relative liver UCP2 mRNA abundance. The relative liver UCP2 mRNA abundance of Chinese carps was determined by PCR amplification of liver cDNA sample within the exponential phase, using beta-actin as an external control. Two common gene-specific PCR primers were used to amplify a $485 \mathrm{bp}$ fragment of UCP2 cDNA: 5'-GGTCCGGTGAAATATCGTG-3' (designated as UCP07F), and 5'-CAGGGAAGATCATCAGTCAT3' (designated as UCP08R). A 436 bp fragment of beta-actin cDNA were amplified by PCR using following two common gene-specific primers: 5'-CGTGACATCAAGGAGAAGC-3' (designated as ACT01F), and 5'-TCTGCTGGAAGGTGGACAG-3' (designated as ACT02R). The PCR products were separated on a $2 \%$ agarose gel and stained with ethidium bromide. The gels were then photographed and analysed by densitometric scaning (Alphalmager ${ }^{\mathrm{TM}}$ ). The relative liver UCP2 cDNA level of Chinese carps was expressed as the ratio $\mathrm{UCP} 2 /$ beta-actin cDNA (\%). Values are expressed as means $\pm \mathrm{SD}$ $(\mathrm{N}=5)$ for each species.

Statistical analysis. Statistical analyses of differences among treatment means were carried out by SPSS1.0. Differences were considered significant if $p<0.05$.

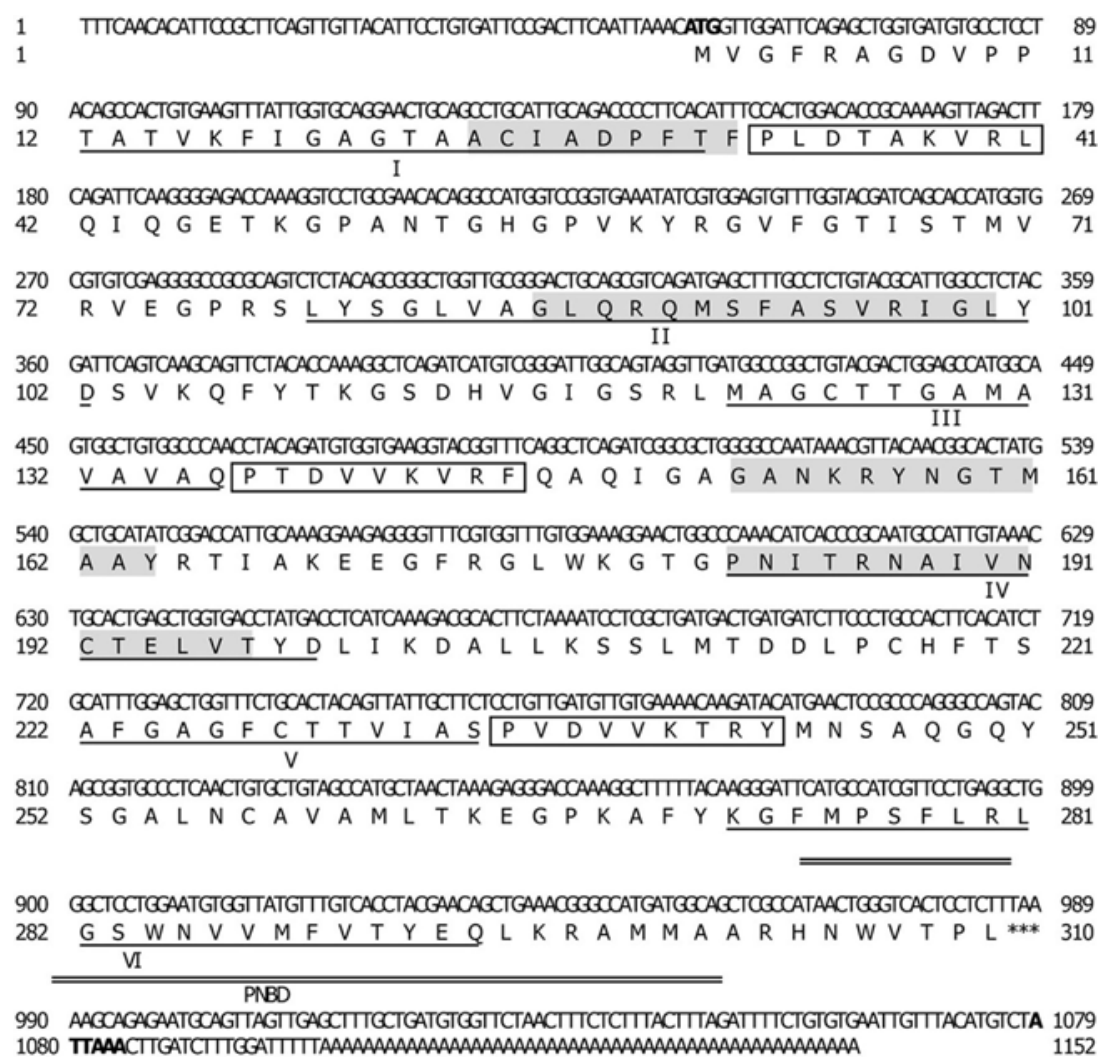

Fig. 1. Nucleotide sequence of grass carp (Ctenopharyngodon idellus) UCP2 cDNA and predicted amino acid sequence. Three asterisks represent a termination codon. The three mitochondrial carrier protein motifs are boxed. The six potential transmembrane $\alpha$-helix domains are single-underlined and labeled by I-VI. The purine-nucleotide domain (PNBD) is double-underlined. The UCP-specific sequences are darkened. The boldfaced (ATTAAA) is polyadenylation signal. The sense strand is displayed from the $5^{\prime}$ to $3^{\prime}$ direction. 


\section{Results}

The full-length grass carp UCP2 cDNA was $1152 \mathrm{bp}$ in length with an open reading frame that encodes 310 amino acids (Fig. 1). The silver carp UCP2 cDNA was 1452 bp in length (data not shown), also encoding 310 amino acids (see also Fig. 4). In the deduced amino acid sequence, three mitochondrial carrier protein motifs, six transmembrane $\alpha$-helix domains, the putative purine-nucleotide binding domains and the UCPspecific sequences, were identified in the UCP2 of grass carp (Fig. 1), and silver carp as well (data not shown) (Ježek and Urbánková, 2000; Hanák and Ježek, 2001; Ishioka et al., 2002).

The size of Exon 3-8 of grass carp UCP2 gene is 223, 214, 195, 102, 181 and $228 \mathrm{bp}$, and Intron 3-7, 357, 102, 160, 80 and 81 bp respectively. All the five introns (Intron 3, 4, 5, 6 and 7) start as GT and end as AG (Fig. 2). It has been reported that, the ratio of exon /intron arrangement of the UCP2 gene in human and mouse is 8/7 (Argyropoulos et al., 1998; Yamada et al., 1998). Structure comparison shows that, the overall UCP2 gene organization of grass carp and mammals remains unchanged, and the length of the exons is almost the same, whereas the length of the introns of the grass carp UCP2 gene (Intron 3, 4, 5, 6, 7 and 8), is slightly shorter than those of mammals (Fig. 3). The similarity of amino acids of translated exons between grass carp and human or mouse, is both 75.4-88.1\% (Table 3).

Partial cDNA sequences of bighead carp and mud carp UCP2 gene, were 542 and 504 bp in length (data not shown), encoding 180 and 168 amino acids, respectively (Fig. 4). Multiple alignment result showed that, the nucleotide and amino acid sequences of UCP2 gene were highly conserved among grass carp, silver carp, bighead carp, mud carp and common carp (common carp sequence was obtained from GenBank, accession number AJ243486) (Fig. 4). For example,

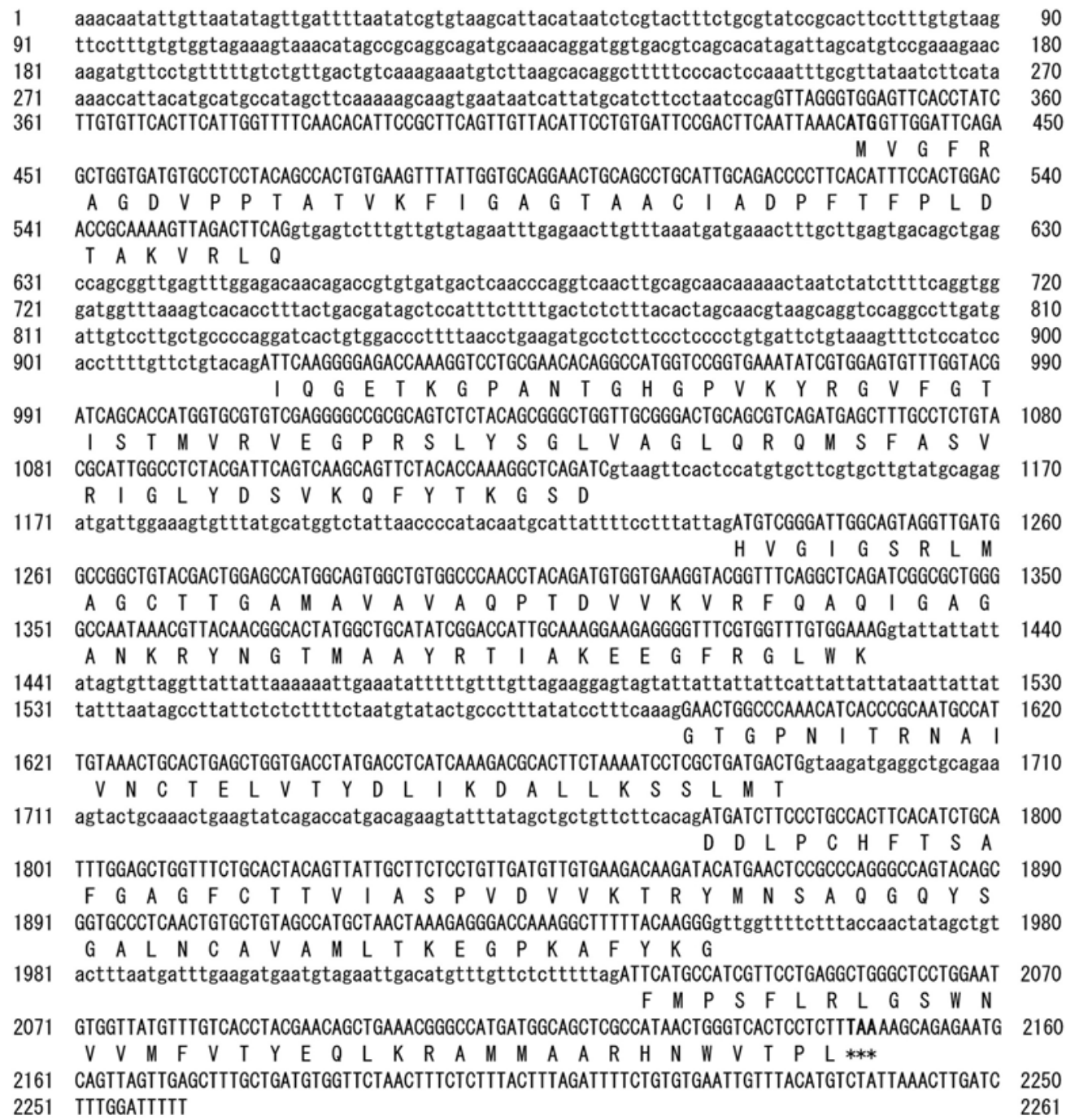

Fig. 2. Nucleotide sequence and structure of protein coding region in grass carp (Ctenopharyngodon idellus) UCP2 gene. The intron sequence is shown in lowercase and exon sequence in uppercase. Three asterisks represent a termination codon. The sense strand is displayed from the $5^{\prime}$ to $3^{\prime}$. 


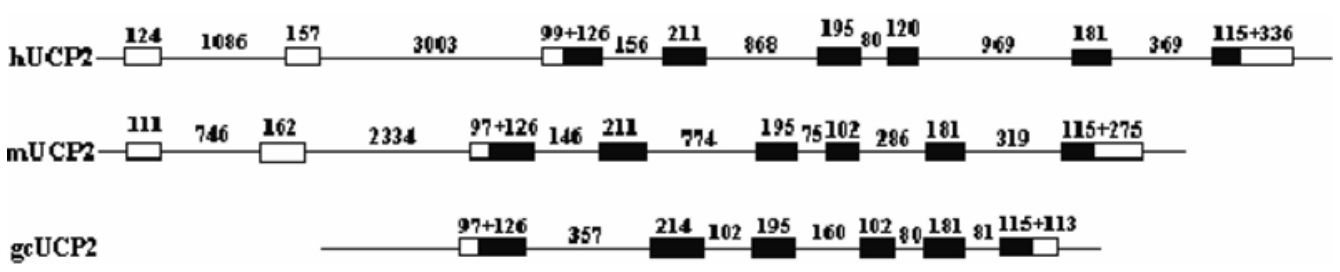

Fig. 3. Primary structure comparison between grass carp (Ctenopharyngodon idellus) UCP2 gene and mammalian UCP2 gene. The sequence of human and mouse UCP2 were obtained from GenBank accession number AF019409 and AB012159 respectively. Exons are shown as boxes (open boxes are untranslated regions) and introns and flanking region are shown in lines. Numbers are base pairs. hUCP2, human UCP2; mUCP2, mouse UCP2; gcUCP2, grass UCP2.

Table 3. Nucleotide and amino acid sequence similarity among exons of grass carp (Ctenopharyngodon idellus) and mammalian UCP2 gene

\begin{tabular}{cccccccc}
\hline \multirow{2}{*}{ Gene compared with grass carp UCP2 } & \multicolumn{5}{c}{ Similarity within exons (\%) } \\
\cline { 3 - 7 } & & 3 & 4 & 5 & 6 & 7 & 8 \\
\hline \multirow{2}{*}{ Human UCP2 } & Nucleotide & 65.4 & 73.1 & 67.2 & 75.7 & 75.1 & 30.2 \\
& Amino acid & 88.1 & 77.5 & 75.4 & 82.4 & 86.7 & 78.9 \\
\hline \multirow{2}{*}{ Mouse UCP2 } & Nucleotide & 63.9 & 76.4 & 68.2 & 76.5 & 75.1 & 33.6 \\
& Amino acid & 88.1 & 77.5 & 75.4 & 79.4 & 85.0 & 76.3 \\
\hline
\end{tabular}

The sequences of human and mouse UCP2 were obtained from GenBank accession number AF019409 and AB012159 respectively.

the similarity of nucleotide sequence between the UCP2 cDNA of grass carp and silver carp, is as high as $97.6 \%$ (Table 4).

UCP2 gene expression was found in the liver of the five major Chinese carps (Fig. 5). Using $\beta$-actin as control, the relative liver UCP2 expression level of these Chinese carps, shows a close relationship with their food habit: benthos and detritus-eating fish (common carp and mud carp) $>$ planktivorious fish (silver carp and bighead carp) $>$ herbivorious fish (grass carp) (Table 5).

\section{Discussion}

In the present study, gene structure and sequence comparison between grass carp and mammalian UCP2 gene clearly shows that, the UCP2 gene of grass carp is completely homologous to that of human and mouse. All the functional domains, including three mitochondrial carrier protein motifs, six transmembrane $\alpha$-helix domains, the putative purinenucleotide binding domains and the UCP-specific sequences, were identified in the UCP2 of grass carp (Fig. 1). Multiple alignment result shows that, the nucleotide and amino acid sequences of the UCP2 cDNA are highly conserved among five major Chinese carps that belong to four different subfamilies (Leuciscinae, Hypophthalmichthyinae, Labeoninae and Cyprininae). It indicates that vertebrate UCP2 might have some basic physiological function in common between territorial and aquatic animals, instead of thermogenesis.

There is evidence showing that, UCP2 modulates the mitochondrial generation of ROS in some cell types, with active ROS production (e.g. immune cells) (Fleury et al., 1997; Negre-Salvayre et al., 1997). The high expression of human UCP2 throughout the immune system, including spleen, thymus, leukocytes, macrophage, etc., strongly suggests a putative role for this protein in immunity (Fleury et al., 1997). This speculation is supported by the work of Larrouy et al. (1997), who found that UCP2 is also expressed at a very high level in Kupffer cells. Although ROS are essential for immune function, including cytotoxic activity (Trinchieri, 1989; De Sanctis et al., 1994), they are basically harmful to tissue cells, as indicated by our previous studies (Hwang and Liang, 1989, 1991; Chen et al., 1992). It is proposed that aerobic cells develop a special protective system against ROS toxicity: the existence of the mild uncoupling of respiration and phosphorylation by means of increased $\mathrm{H}^{+}$leak through the mitochondrial inner membrane (Skulachev, 1996; Ricquier and Bouillaud, 2000). The high level of UCP2 expression in the immune system, might be a protective response to the active ROS production in the immune cells.

Liver is the major site in fish and other vertebrates for the detoxification of ingested toxic materials (e.g. cyanobacterial toxins) by oxidation, and ROS is known to be involved in the process (Hermansky et al., 1991; Ding et al., 1998; Gehringer et al., 2003). Our previous work on fish UCP2 gene expression in vivo, has found that UCP2 was highly expressed in the liver of red sea bream but was almost not able to be detected in the visceral adipose tissue of this fish. The striking contrast of UCP2 gene expression in the two fish tissues is completely consistent to the great distinction of their oxidative capacity (Liang et al., 2003). In the present study, substantial 


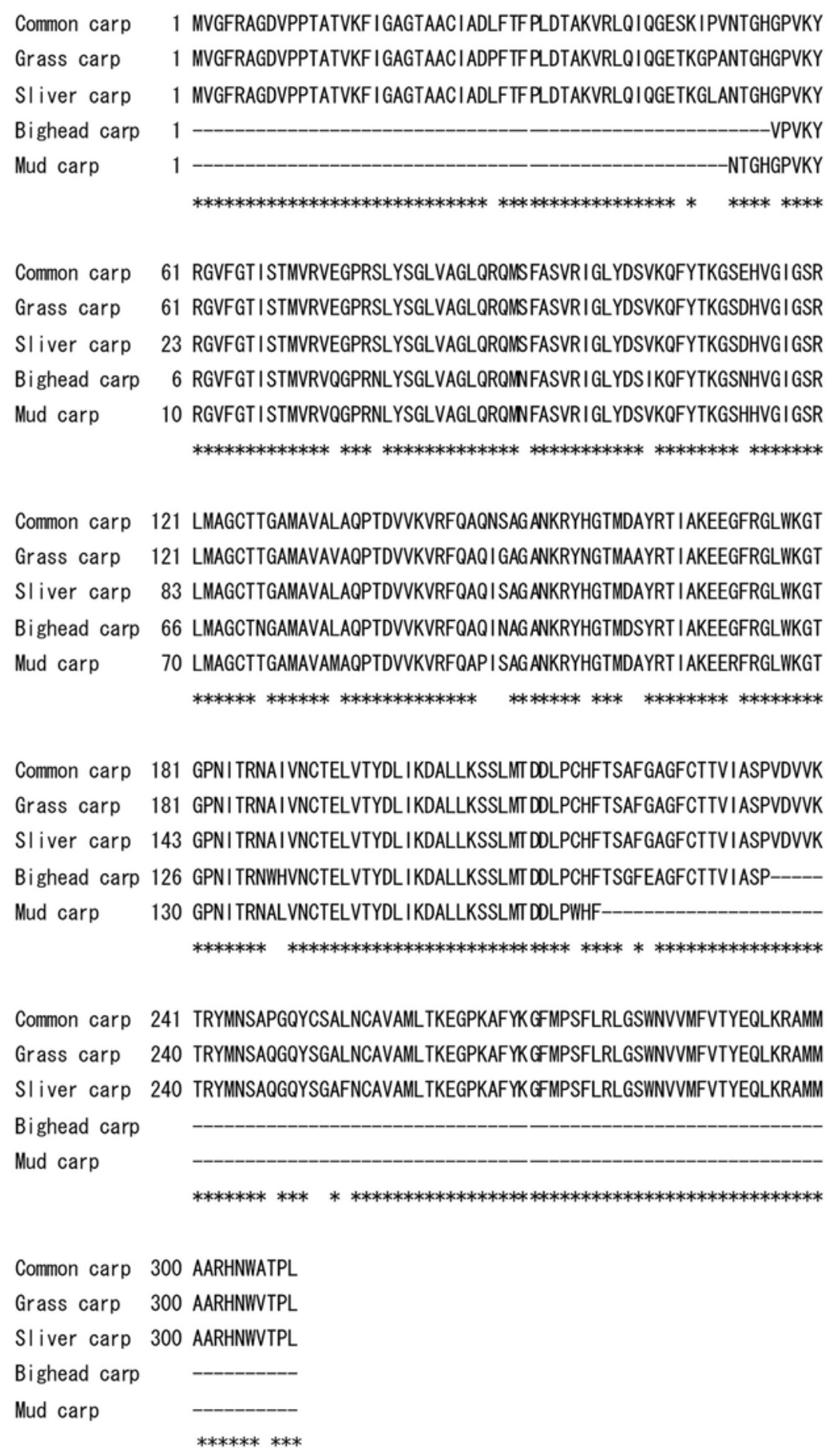

Fig. 4. Amino acid sequence alignment of five major Chinese carp UCP2. The amino acid sequence of common carp (Cyprinus carpio) UCP2 was obtained from GenBank (AJ243486). Dashes indicate the amino acid gaps that are necessary to align these sequences. The conserved residues in all sequences are indicated by asterisk $\left(^{*}\right)$.

amount of liver UCP2 expression was found in all the five major Chinese carps, indicating that UCP2 might be necessary to these Chinese carps for some basic function of their liver.

Cyanotoxins produced by freshwater cyanobacteria are very common worldwide, especially in China, and have been reported to cause poisonings and deaths of wild and domestic animals (Codd, 1995; Dawson, 1998; Carmichael, 2001), and even significant hazards to human health (Yu, 1995; Pouria et al., 1998). In aquatic ecosystems, fish stand at the top of the aquatic food chain, and are possibly affected by exposure to toxic cyanobacteria. Many experimental studies have been conducted to document the liver accumulation, toxicity and 
Table 4. Homology (\%) of nucleotide and deduced amino acid sequence among the major Chinese carp UCP2

\begin{tabular}{clcccc}
\hline & & Silver carp & Bighead carp & Mud carp & Common carp \\
\hline \multirow{2}{*}{ Grass carp } & Nucleotide & 97.6 & 91.9 & 91.6 & 94.0 \\
& Amino acid & 97.4 & 91.6 & 92.3 & 96.1 \\
\hline \multirow{2}{*}{ Silver carp } & Nucleotide & & 93.6 & 92.0 & 94.8 \\
& Amino acid & 93.5 & 94.2 & 98.7 \\
\hline \multirow{2}{*}{ Bighead carp } & Nucleotide & Amino acid & & 99.7 & 90.6 \\
& Nucleotide & & 92.9 & 92.9 \\
\hline \multirow{2}{*}{ Mud carp } & Amino acid & & & 93.3 \\
& & & 93.5 \\
\hline
\end{tabular}

The nucleotide and amino acid sequence of common carp (Cyprinus carpio) UCP2 was obtained from GenBank (AJ243486).

(A)

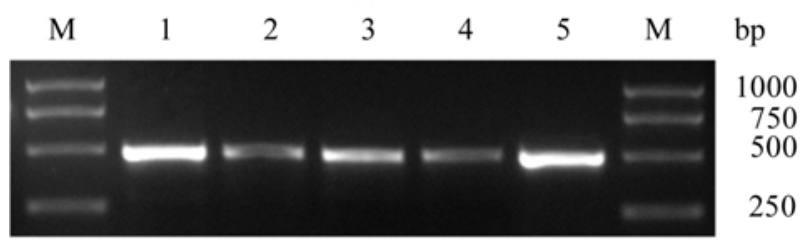

(B)

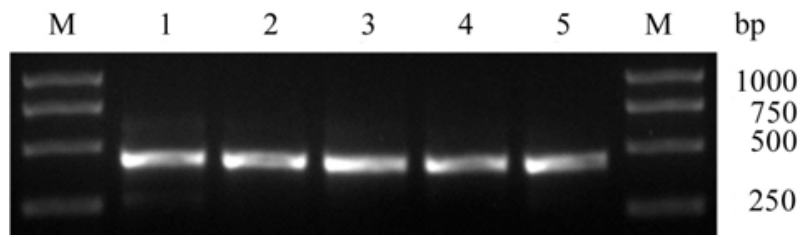

Fig. 5. Analysis of UCP2 (A) and $\beta$-actin (B) mRNA expression in the liver of Chinese carps by RT-PCR. M marker; 1 common carp (Cyprinus carpio); 2 grass carp (Ctenopharyngodon idellus); 3 silver carp (Hypophthalmichthys molitrix); 4 bighead carp (Aristichthys nobilis); 5 mud carp (Cirrhinus molitorella).

depuration of microcystin exposure through gastrointestinal way on (1) benthos and detritus-eating fish, such as common carp and mud carp, (2) planktivorous fish such as silver carp and bighead carp, and (3) macrophytes-eating herbivorous fish such as grass carp (Chen et al., 1995; Zhang et al., 1996; Fischer and Dietrich, 2000; Li et al., 2001; Wu et al., 2002; Liu and Xie, 2003; Xie et al., 2004). The five major Chinese carps are especially important in China, because of their impact on aquatic ecosystems and importance as food fish (Liu, 1990).

The present study has demonstrated that, the relative liver UCP2 expression of the five major Chinese carps shows a close relationship with their food habit: benthos and detrituseating fish (common carp and mud carp) is the highest, followed by planktivorous fish (silver carp and bighead carp), and herbivorous fish (grass carp) is the lowest. We should also point out that translational regulation of the UCP2 mRNA has been shown for human UCP2 expression under stress conditions
Table 5. UCP2 gene expression in the liver of Chinese carps

\begin{tabular}{lc}
\hline Species & Ratio UCP2/ $\beta$-actin mRNA $(\%)$ \\
\hline Common carp & $149.4 \pm 15.6^{\mathrm{a}}$ \\
Mud carp & $127.4 \pm 22.1^{\mathrm{a}}$ \\
Silver carp & $96.7 \pm 12.7^{\mathrm{b}}$ \\
Bighead carp & $94.1 \pm 26.8^{\mathrm{b}}$ \\
Grass carp & $63.7 \pm 16.2^{\mathrm{c}}$ \\
\hline
\end{tabular}

Values are expressed as means $\pm \mathrm{SD}(\mathrm{N}=5)$ for each species. A value followed by a superscript differs significantly $(p<0.05)$ from all other values not followed by the same superscript.

(Pecqueur et al., 2001). It still needs to be determined whether translational regulation may exist for the fish UCP2 expression under our experimental condition. It has been known that, the amount of cyanotoxin and bacteria is generally higher in the detritus than in the plankton of water column, and the aquatic plants fed by grass carp, usually has little cyanotoxin or other toxic substances (Liu, 1990). The speculated cyanotoxin and bacteria content in the food of the five major Chinese carps, coincides well with their liver UCP2 expression level. The liver UCP2 expression level of the five major Chinese carps appears to be greatly affected by the content of the toxic materials in their food. Because oxidation and ROS generation is necessarily involved in the detoxification process of cyanotoxins in hepatocytes, and active ROS production is also essential for Kupffer cells to eliminate toxic bacteria from liver, the high expression of liver UCP2 in detritus-eating fish (common carp and mud carp) and planktivorous fish (silver carp and bighead carp), might be important to restrain over production of ROS and protect the fish liver from apoptosis. In conclusion, UCP2 gene structure and coding sequence are highly conserved among five major Chinese carps and mammals, indicating that vertebrate UCP2 might have some basic physiological function in common between territorial and aquatic animals, instead of thermogenesis. Substantial amount of liver UCP2 expression was found in all the five major Chinese carps, and their relative liver UCP2 expression shows a close relationship with their food habit. We suggest 
that liver UCP2 might be important for Chinese carps to detoxify cyanotoxins and bacteria in debris and plankton food.

Acknowledgments We wish to express our thanks to Dr. Jeffrey T. Silverstein for his helpful review of the manuscript. This work was financially supported by the Scientific Research Foundation for the Returned Overseas Chinese Scholars, the Project of Natural Science Foundation of Guangdong Province (031886) and the Project of Science and Technology of Guangdong Provice (2005B20301005).

\section{References}

Argyropoulos, G., Brown, A. M., Peterson, R., Likes, C. E., Watson, D. K. and Garvey, W. T. (1998) Structure and organization of the human uncoupling protein 2 gene and identification of a common biallelic variant in Caucasian and African-American subjects. Diabetes 47, 685-687.

Carmichael, W. W. (2001) Health effects of toxin-producing cyanobacteria: "the CyanoHABs". Hum. Ecol. Risk. Assess. 7, 1393-1407.

Chen, J. C., Hu, Y. D. and Zhang, R. T. (1995) Studies on the toxic effects of Microcystis on fishes. Fishery Science Information 22, 169-171.

Chen, J. W., Zhang, L. P., Liang, X. F. and Hwang, F. (1992) Effect of hydroxyl radical on Na-K-ATPase activity of the brain microsomal membranes. Cell Biol. Int. Rep. 16, 927-936.

Codd, G. A. (1995) Cynobacterial toxins: occurrence, properties and biological significance. Wat. Sci. Technol. 32, 149-156.

Dawson, R. M. (1998) The toxicology of microcystins. Toxicon 36, 953-962.

De Sanctis, J. B., Blanca, I., Radzioch, D. and Bianco, N. E. (1994) Lipoprotein lipase expression in natural killer cells and its role in their cytotoxic activity. Immunology 83, 232-239.

Ding, W. X., Shen, H. M., Zhu, H. G. and Ong, C. N. (1998) Studies on oxidative damage induced by cyanobacterial extract in primary cultured rat hepatocytes. Environ. Res. 78, 12-18.

Echtay, K. S., Roussel, D., St-Pierre, J., Jekabsons, M. B., Cadenas, S., Stuart, J. A., Harper, J. A., Roebuck, S. J., Morrison, A., Pickering, S., Clapham, J. C. and Brand, M. D. (2002) Superoxide activates mitochondrial uncoupling proteins. Nature 415, 96-99.

Fischer, W. J. and Dietrich, D. R. (2000) Pathological and biochemical characterization of Microcystin-induced hepatopancreas and kidney damage in Carp (Cyprinus carpio). Toxicol. Appl. Pharmacol. 164, 73-81.

Fleury, C., Neverova, M., Collins, S., Raimbault, S., Champigny, O., Levi-Meyrueis, C., Bouillaud, F., Seldin, M. F., Surwit, R. S., Ricquier, D. and Warden, C. H. (1997) Uncoupling protein 2: a novel gene linked to obesity and hyperinsulinemia. Nat. Genet. 15, 269-272.

Gehringer, M. M., Downs, K. S., Downing, T. G., Naudé, R. J. and Shephard, E. G. (2003) An investigation into the effect of selenium supplementation on microcystin hepatotoxicity. Toxicon 41, 451-458.

Hanák, P. and Ježek, P. (2001) Mitochondrial uncoupling protein and phylogenesis-UCP4 as the ancestral uncoupling protein. FEBS Lett. 495, 137-141.
Hermansky, S. J., Stohs, S. J., Eldeen, Z. M., Roche, V. F. and Mereish, K. A. (1991) Evaluation of potential chemoprotectants against microcystin-LR hepatotoxicity in mice. J. Appl. Toxicol. 11, 65-74.

Hwang, F. and Liang, X. F. (1989) Spin-trapping studies of free radicals in human erythrocytes. Stud. Biophys. 134, 105-110.

Hwang, F. and Liang, X. F. (1991) Damage to membrane lipids and proteins of brain microsomes by hydroxyl radicals. Acta Biophys. Sinica 7, 223-226.

Ishioka, K., Kanehira, K., Sasaki, N., Kitamura, H., Kimura, K. and Saito, M. (2002) Canine mitochondrial uncoupling proteins: structure and mRNA expression of three isoforms in adult beagles. Comp. Biochem. Physiol. B 131, 483-489.

Ježek, P. and Urbánková, E. (2000) Specific sequence motifs of mitochondrial uncoupling proteins. IUBMB Life 49, 63-70.

Larrouy, D., Laharrague, P., Carrera, G., Viguerie-Bascands, N., Levi-Meyrueis, C., Fleury, C., Pecqueur, C., Nibbelink, M., Andre, M., Casteilla, L. and Ricquier, D. (1997) Kupffer cells are a dominant site of uncoupling protein 2 expression in rat liver. Biochem. Biophys. Res. Commun. 235, 760-764.

Li, X. Y., Liu, Y. D. and Song, L. R. (2001) Cytological alterations in isolated hepatocytes from common carp (Cyprinus carpio L.) exposed to microcystin-LR. Environ. Toxicol. 16, 517-522.

Liang, X. F., Ogata, H. Y., Oku, H., Chen, J. and Hwang, F. (2003) Abundant and constant expression of uncoupling protein 2 in the liver of red sea bream Pagru major. Comp. Biochem. Physiol. A 136, 655-661.

Liu, J. (1990) Lake Donghu Ecological Research. Beijing: Science Press 1-407.

Liu, J. K. and Xie, P. (2003) Direct control of microcysis bloom through the use of planktivorous carp-closure experiments and lake fishery practice. Ecoligic Sicence 22, 193-196.

Negre-Salvayre, A., Hirtz, C., Carrera G, Cazenave, R., Troly, M., Salvayre, R., Penicaud, L. and Casteilla, L. (1997) A role for uncoupling protein-2 as a regulator of mitochondrial hydrogen peroxide generation. FASEB J. 11, 809-815.

Nicholls, D. G. and Locke, R. M. (1984) Thermogenic mechanisms in brown fat. Physiol. Rev. 64, 1-64.

Pecqueur C., Alves-Guerra M. C., Gelly C, Levi-Meyrueis C., Couplan E., Collins S., Ricquier D., Bouillaud F., and Miroux B. (2001) Uncoupling protein 2, in vivo distribution, induction upon oxidative stress, and evidence for translational regulation. J. Biol. Chem. 276, 8705-8712.

Pouria, S., Andrade, A. D., Barbosa, J., Cavalcanti, R. L., Barreto, V. T. S., Ward, C. J., Preiser, W., Poon, G. K., Neild, G. H. and Codd, G. A. (1998) Fatal microcystin intoxication in haemodialysis unit in Caruaru, Brazil. Lancet 352, 21-26.

Rabergh, C. M. I., Bylund, G. and Eriksson, J. E. (1991) Histopathological effects of microcystin-LR, a cyclic peptide toxin from the cyanobacterum (blue-green alga). Aquat. Toxicol. 20, 131-146.

Ricquier, D. and Bouillaud, F. (2000) The uncoupling protein homologues: UCP1, UCP2, UCP3, StUCP and AtUCP. Biochem. J. 345, 161-179.

Samec, S., Seydoux, J. and Dulloo, A. G. (1998) Role of UCP homologues in skeletal muscles and brown adipose tissue: mediators of thermogenesis or regulators of lipids as fuel substrate? FASEB J. 12, 715-724.

Skulachev, V. P. (1996) Why are mitochondria involved in 
apoptosis? Permeability transition pores and apoptosis as selective mechanisms to eliminate superoxide-producing mitochondria and cell. FEBS. Lett. 397, 7-10.

Stuart, J. A., Happer, J. A., Brindle, K. M. and Brand, M. D. (1999) Uncoupling protein 2 from carp and zebrafish, ectothermic vertebrates. Biochem. Biophys. Acta 1413, 50-54.

Trinchieri, G. (1989) Biology of natural killer cells. Adv. Immunol. 47, 187-376.

Wu, W., Qu, J. H., Chen, J. Z., Hu, G. D. and Liu, H. (2002) Toxicological effects on the fish liver by microcystins. China Environ. Sci. 22, 67-70.

Xie, L. Q., Xie, P., Ozawa, K., Honma, T., Yokoyama, A. and Park, H. (2004) Dynamics of microcystins-LR and -RR in the phytoplanktivorous silver carp in a sub-chronic toxicity experiment. Environ. Pollut. 127, 431-439.

Yamada, M., Hashida, T., Shibusawa, N., Iwasaki, T., Murakami, M., Monden, T., Satoh, T. and Mori, M. (1998) Genomic organization and promoter function of the mouse uncoupling protein 2 (UCP2) gene. FEBS Lett. 432, 65-69.

Yu, S. J. (1995) Primary prevention of hepatocelluar carcinoma. $J$. Gastroenterol. Hepatol 10, 674-682.

Zhang, Y. Y., Xu, L. H., Zhou, B. S. and Xu, Y. (1996) Preliminary studies on the role of GSH in detoxification of microcystin-LR in fish. Acta Hydrobiologica Sinica 20, 284286. 